\title{
Analysis of the India-Myanmar timber trade
}

\author{
ELODIE MARIA-SUBE ${ }^{1, \bullet}$, GRAHAM WOODGATE ${ }^{2, \bullet \bullet}$ \\ 1European Union Delegation to Myanmar, Hledan Centre, Yangon, Myanmar. Tel.: +959782712141, ^email: elodiems@gmail.com.

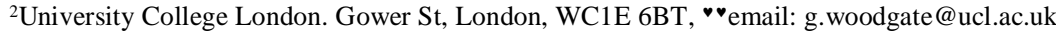

Manuscript received: 22 June 2018. Revision accepted: 11 October 2018.

\begin{abstract}
Maria-Sube E, Woodgate G. 2019. Analysis of the India-Myanmar Timber Trade. Asian J For 3: 1-9. Myanmar's forest cover declined by $1.8 \%$ annually between 2000 and 2015 as the result of on-going civil wars and institutional weaknesses. As Myanmar transitioned from military dictatorship, round log exports were banned in 2014. Until 2014, India was the most important importer of timber from Myanmar in terms of value, and the second most important in terms of volume, after China. This article assesses the value and volume of timber traded between Myanmar and India from 2010 until 2015. In addition to trade flows, the timber species and main actors involved in the timber trade are identified and the governance environment of trade is assessed. The paper goes on to inves tigate the impact of recent regulatory changes enacted by the Government of India and the prospects for the future of the India-Myanmar trade. The analysis showed that (i) from an economic perspective, the timber trade between the two countries, once active, is currently stalled. (ii) From a governance perspective, illegality occurs to a limited extent at the international border but probably happens to a greater extent at timber auctions in Myanmar. Finally (iii), from a social and environmental point of view, as infrastructure expands it will be crucial to include forest management and timber trade governance in discussions regarding border relations between the two countries.
\end{abstract}

Keywords: India, governance, Myanmar, timber, trade

\section{INTRODUCTION}

At the beginning of the $20^{\text {th }}$ century, Burma (Myanmar) was famous worldwide for the science-based management of its teak forests and its high volume of exports (Woods and Canby 2011). However, successive government upheavals and on-going internal conflicts since independence have severely impacted the country's forests. From its independence in 1948 until the military coup in 1962, Myanmar's forests were managed according to colonial rules; after 1962, and in particular, after the civil uprisings in 1988, forests were logged unsustainably (Springate et al. 2016). Between 2000 and 2015, Myanmar experienced the third greatest loss of forest cover in the world, with an annual deforestation rate of 546,000 ha (equivalent to $1.8 \%$ of its forested area), behind only Indonesia and Brazil (FAO 2015a). In April 2014, the Myanmar government decided to ban the export of round logs. This was followed by a total logging ban from August 2016 until March 2017. The Environmental Investigation Agency commented that these measures 'give grounds for hope that Myanmar is entering a new era of forest management in which conservation and transparency, rather than the old model of extract and export, are at the fore' (EIA 2016a).

There is no undisputed definition of what illegal logging entails and no worldwide regulation to combat illegal logging. A recent definition (Kleinschmit et al. 2016, p.14) includes 'all practices related to the harvesting, processing, and trading of timber inconsistent with national and sub-national law'. Consumer countries have made bilateral or national efforts to reduce illegal logging and better manage forests internationally since the 1990s. Laws restricting imports of illegally harvested wood were passed in the United States with the 2008 Lacey Act and in the EU with the 2010 Timber Regulation. Such laws are slowly proving effective. In November 2016, a Swedish court ruled that a Singaporean trader's proof of legality for a shipment of Myanmar teak was not sufficient under the EU Timber Regulation (Forest Trends 2016). As a consequence, no Burmese teak can now be placed in the EU market (EIA 2016b).

Today, the rapidly expanding economies of China and India together represent $72 \%$ of global tropical log imports compared to just $28 \%$ in 2000 (Gan et al. 2016). In the case of Myanmar, the value of timber exports to China reached USD 621 million in 2013, of which more than 90\% was thought to have been illegally logged (Woods 2013b). India was the main importer of timber from Myanmar until 2013 in terms of value, yet there is very little published research on this topic. There are also no studies yet investigating the impact of the recent timber export bans on the IndiaMyanmar timber trade. Therefore, this research aims to: quantify the value and volume of timber traded between Myanmar and India over the past 15 years; to identify where the timber transits between the two nations; and to assess the main actors involved and the species of timber traded. The main products to be studied are logs, sawn wood, veneer, and plywood. The governance of the trade will be analyzed, as well as recent changes in the IndiaMyanmar relationship context and the future prospects for the trade.

The information presented in this paper is expected to provide a better understanding on the issue of the IndiaMyanmar timber trade in this new global and bilateral context. It would answer the following questions: (i) What 
are the characteristics of the India-Myanmar timber trade since 2000? (ii) What are the economic, environmental and governance effects of the recent tightening of regulations on timber trade between India and Myanmar?

The paper develops as follows. A review of the literature surrounding forest management and timber production in Myanmar and the characteristics of the timber trade relationship between Myanmar and India, the materials and methods are explained. In the subsequent section, the results are presented and discussed.

\section{MATERIALS AND METHODS}

\section{Quantitative research design}

The quantitative research aimed to establish the volume, value, and flows of the India-Myanmar timber trade over the past 15 years. The analysis focused on all wood-based products other than paper and fuelwood, i.e., logs, sawn wood, veneer, plywood, and wooden furniture or ornaments, the main elements covered by Voluntary Partnership Agreements (VPAs) with the European Commission, called core VPA products. This scope facilitates comparisons with other sets of data.

Data were collected from three secondary sources: (i) the independent website www.flegtactionplan.eu, which collates information from open sources, such as the UN Comtrade database and Ministries of Commerce of importing countries; this source was used to compile Myanmar timber exports data and India's imports by country of origin; (ii) the UN Comtrade database, which contains official trade statistics shared by UN Member States; this source was used to cross-check Indian imports by country of origin in the flegtactionplan.eu website and to produce graphs of India's imports from Myanmar by wood product in terms of volume and value; (iii) The Directorate General of Commercial Intelligence and Statistics, Ministry of Commerce and Industry, Government of India; this source provided data regarding ports of entry of Indian imports. Data can only be obtained free for transactions within the last 24 months. Port of entry data was retrieved for imports of wood products from Myanmar and of wood products from all other countries in 2015.

Data were not altered, except the volume data for imports of logs, sawn wood, veneer, plywood, and other smaller wooden products. UN Comtrade provides weight data but not volume. In addition, volume of a wood product underestimates the volume of roundwood needed to make that product. Analysts calculate a roundwood equivalent. EU FLEGT conversion factors were used to transform data where necessary (Table 1).

\section{Qualitative research design}

The qualitative research aimed to answer questions related to the actors involved in the trade, the species that are traded, and the governance of the trade, as well as future prospects for this trade. Initial contacts were identified and these provided further informants, following a snowball sampling technique. Drawn from government, the private sector, academia, development partners and NGOs in India and Myanmar, 32 individuals were contacted for interviews between March and June 2017. Thirteen respondents accepted and were interviewed for durations ranging from 30 minutes to 2 hours. Protocols were prepared for semi-structured interviews for four respondent groups: Private sector, development partners, NGOs in India and NGOs in Myanmar.

Interviews with respondents based in India, took place between 10 and 19 April 2017, in New Delhi and Shillong, in the North East of India. Three interviews with Indiabased respondents also took place by telephone and one interviewee answered in writing. Interviews in Myanmar were all face-to-face. All but one respondent agreed to be recorded.

Qualitative data were analyzed using Dedoose Version 7.6 software. Themes within the interview transcripts were coded to identify trends in answers. Trends were not identified, given the diversity of respondents, but this exercise helped categorize the analysis regarding two topics: the governance of the sector and the future of the trade.

Some respondents stated that they did not wish to be named or to have their organizational affiliation revealed. This preference was therefore applied to all respondents, in order to avoid any issues with confidentiality. Table 2 details the sector and country of origin of respondents.

\section{RESULTS AND DISCUSSION}

\section{Size of the trade: volume and value}

In terms of volume, India imported on average $42 \%$ of Myanmar's global timber exports between 2000 and 2015: in total 11.86 million $\mathrm{m}^{3}$ Round Wood Equivalent (RWE) The value of Indian imports from Myanmar peaked in 2013 when they totaled more than US\$700 million, and accounted for $31 \%$ of all of India's timber imports in that year. Myanmar was then the main source of timber in terms of value, ahead of Malaysia, for three years from 2011 to 2013. This peak was followed by a slight decrease in 2014, followed by a sharper decline in 2015 and 2016 (Figure 1).

India's demand for timber had increased four times in value and doubled in volume since 2000. As can be seen in Figure 2, Malaysia was one of the main sources of timber for India in terms of value and volume since 2000. In 2016, Malaysia was the primary source in terms of value, while New Zealand represented the most important source in terms of volume. At the same time, India has diversified considerably its sources of timber with the growth in 'other' sources.

\section{Wood products traded}

Both in terms of value and volume, timber traded from Myanmar to India was predominantly composed of round logs until the export ban was announced in 2014, varying between $95 \%$ and $99 \%$ of the total value of the trade. Despite the round-log ban in April 2014, a significant volume of logs, more than $75 \%$ of the value of timber traded in 2015 , were exported to India in one quarter. One 
Myanmar-based interview respondent from an international organization explained that the log export ban might not have been well planned. In the run-up to the ban, many more trees were felled, to create stockpiles, which could be legally traded.

Table 1. Roundwood Estimates (RWE) measures

\begin{tabular}{ll}
\hline Data & $\begin{array}{c}\text { Weight to volume } \\
\text { conversion }\end{array}$ \\
\hline Determination of volume by weight & Multiply by 1.4 \\
Fibreboard and sawn wood volume & Multiply by 1.8 \\
Veneer and Mouldings volume & Multiply by 1.9 \\
Plywood volume & Multiply by 2.3 \\
Wooden furniture volume & Multiply by 2.8 \\
Picture frames, ornaments, joinery & Multiply by 2.5 \\
volume or non-specified articles &
\end{tabular}

In 2015, the amount of timber traded plummeted by $61 \%$ in terms of volume (see Figure 3 ) and $79 \%$ in terms of value (Figure 4). The amount of logs exported is not zero, but small. The amount of veneer and sawn wood traded suddenly increased. Veneer represented $69 \%$ of the total value of timber traded in 2016 and sawn wood $24.5 \%$.

Table 2. Profiles of respondents

\begin{tabular}{lccc}
\hline Sector/country of operation & India & Myanmar & Total \\
\hline Academic & 2 & & 2 \\
Development Partner/ & 1 & 1 & 2 \\
International Organisation & & & \\
Government & 1 & & 1 \\
NGO & 2 & 2 & 4 \\
Private Sector & 2 & 2 & 4 \\
Total & 8 & 5 & 13 \\
\hline
\end{tabular}

Note: Extracted from Dedoose 7.6

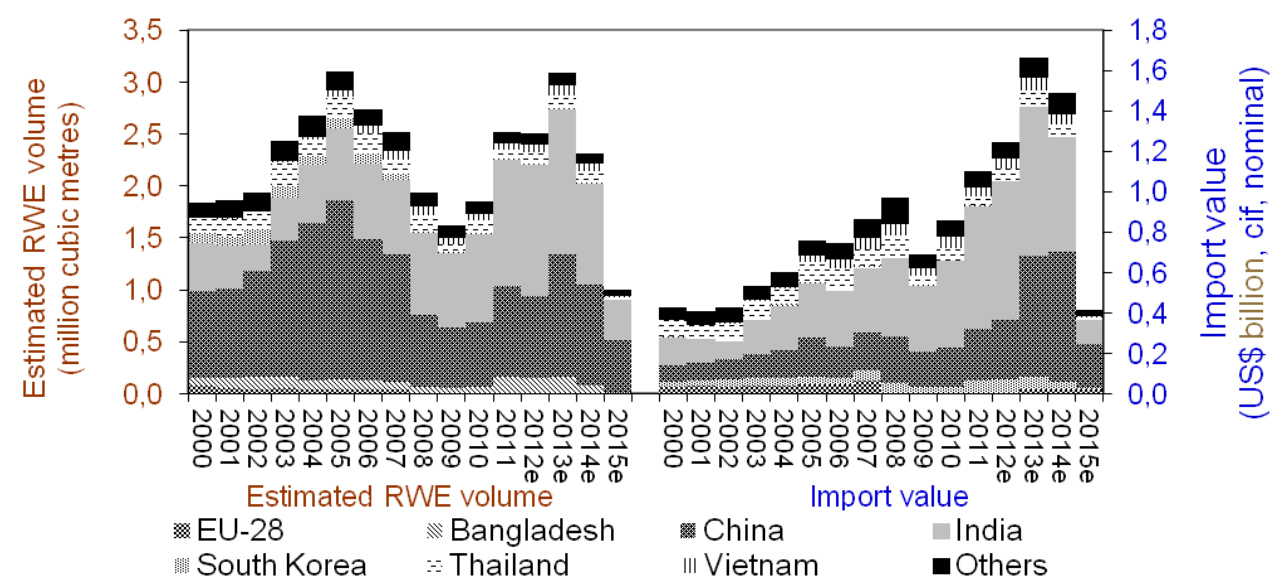

Figure 1. Imports of core VPA products from Burma (by importing country) based on declarations by importing country. Source: EU FLEGT Action Plan, data retrieved on 19 June 2017, http://flegtactionplan.eu/noneuimportsandexports.htm. The sources of the trade statistics used include: General Administration of Customs of the People's Republic of China (for China), Eurostat (for imports by EU member states), Import Statistics of Japan (for Japan), Korea Customs Service (for South Korea), Tradeline Philippines (for the Philippines), Directorate General of Customs (for Taiwan), Customs Department of the Kingdom of Thailand (for Thailand), United States International Trade Commission DataWeb (for the USA) and UN Comtrade

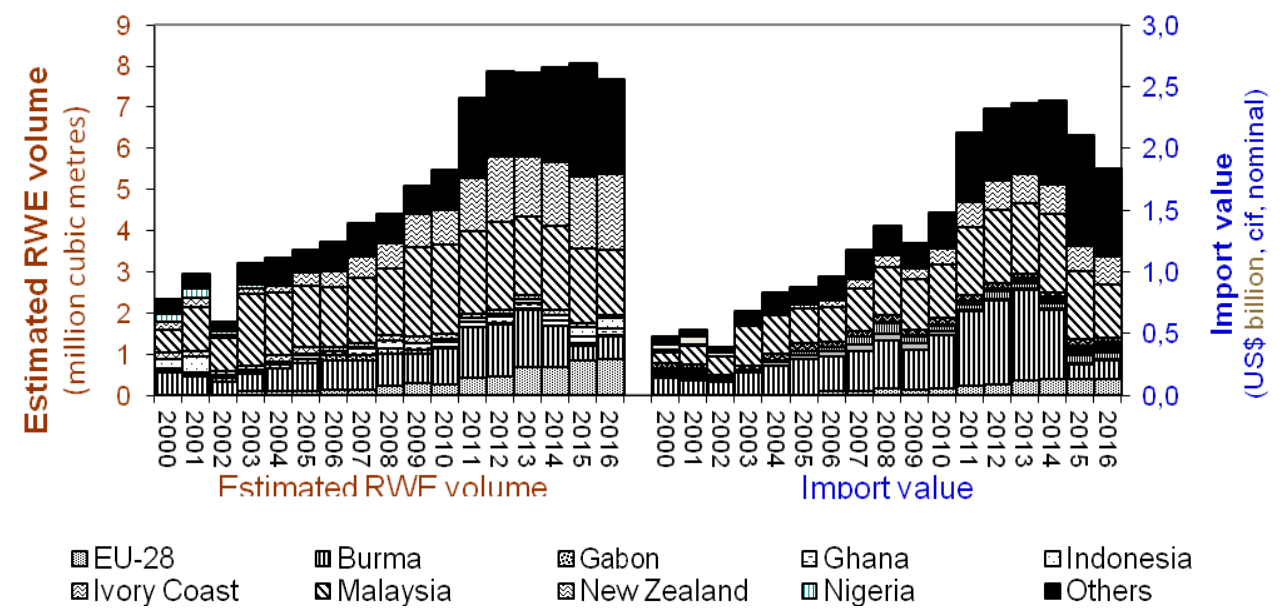

Figure 2. India's imports of core VPA products-by supplying country. Source: EU FLEGT Action Plan, data retrieved on 19 June 2017 , http://flegtactionplan.eu/noneuimportsandexports.htm 
Interviews revealed that in terms of species, Burmese teak, Tectona grandis, is highly appreciated by Indian traders. Interestingly, private sector respondents based in Myanmar did not mention teak; they focused on other species. Their prudence could be explained by the recent European sanctions. Burmese teak is not included on the IUCN Red List, nor in the CITES Appendices. Respondents with greater technical knowledge of the market, said gurjan, Dipterocarpus spp., as a preferred species for veneer and plywood. According to one private sector respondent operating in Myanmar, Myanmar exports 60 to $70 \%$ of its gurjan to India. Teak is mainly found in the forests of Sagaing. Several Dipertocarpus species are listed on the IUCN Red List as critically endangered, though they are not in the CITES Appendices. It can be difficult to tell these species apart in the trade, as gurjan may refer to a range of species. Desraj notes a similar phenomenon, noting that the Burmese name 'Kanyin' is actually 'rather loosely applied to probably a dozen species found throughout Burma' (1961). The third species mentioned is pyinkado, commonly called Ironwood (Xylia xylocarpa). It is used principally for construction and is not listed in the IUCN Red List.

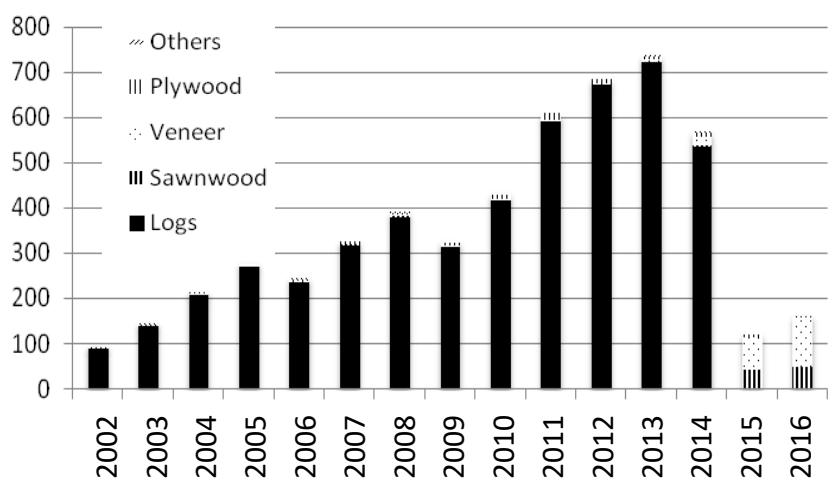

Figure 3. Imports of core VPA products from Myanmar to India in terms of value (millions of USD). Source: UN Comtrade from 2002 to 2016 for codes 4403, 4407, 4408, 4409, 4411, 4412, 4414, 4418, 4420, 940161, 940169, 940330, 940340, 940350, 940360

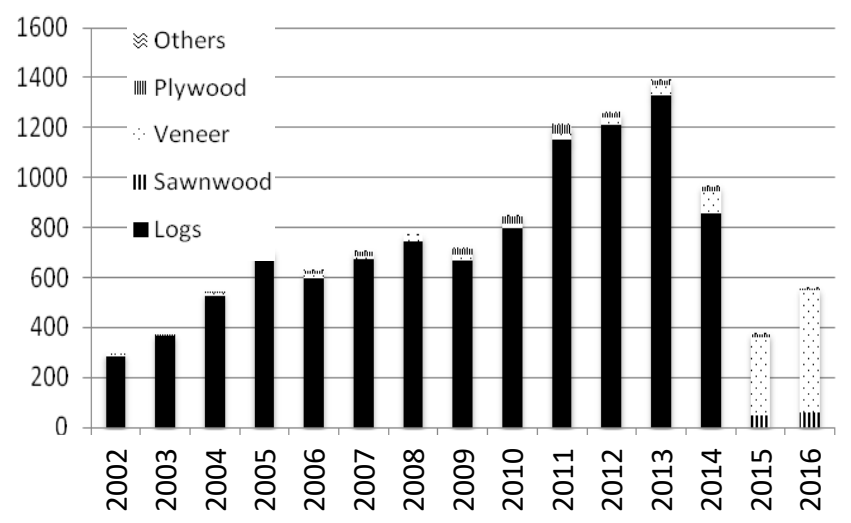

Figure 4. Imports of core VPA products from Myanmar to India in terms of volume in RWE. Source: UN Comtrade from 2002 to 2016 for codes 4403, 4407, 4408, 4409, 4411, 4412, 4414, 4418, 4420, 940161, 940169, 940330, 940340, 940350, 940360

\section{Trade flows}

Data could only be obtained for the year 2015 from the Indian Ministry of Commerce and Industry. As the roundwood ban had already been implemented that year in Myanmar and the nature of the wood products traded had changed significantly in that period, data were extracted for flows from Myanmar and for global ones.

While the main ports of entry for India's US\$2.4 billion timber imports in 2015 were Kandla and Mundra, both located in Gujarat (Table 3), the main port of entry for timber from Myanmar was Cochin in Kerala (Table 4). Kandla has installed significant wood processing facilities at its port (ITTO 2013). Kolkata, was the third most important point of entry for imports from Myanmar in 2015, while it was much less important in terms of global flows. The headquarter of a plywood company called CenturyPly, which had a factory in Myanmar, is located in Kolkata. It is possible that round logs previously transited through Kandla and Mundra and that today, processed wood is transiting through Chennai and Kolkata.

"Other ports" are notable in both tables, for the flows from Myanmar and the global flows. As noted by a respondent operating in the private sector in India, Indian companies active in the timber sector were of small and medium size. Their flows were smaller and they might import their timber through smaller ports.

Table 3. Ports of entry into India of 'Plywood and Allied Products' and 'Other Wood and Wood Products' from all sources, Value in US Dollars, 2015

\begin{tabular}{lr}
\hline Port of entry & Value US\$ \\
\hline Kandla & $626,454,475$ \\
Mundra & $342,825,976$ \\
Other Ports & $234,847,090$ \\
Chennai & $222,168,969$ \\
Tuticorin & $210,253,986$ \\
Nhava Sheva & $184,199,852$ \\
Kolkata & $183,464,093$ \\
Delhi (ICD) & $131,983,971$ \\
Cochin & $91,966,107$ \\
ICD Bangalore & $81,321,901$ \\
Marmagoa & $46,747,885$ \\
New Mangalore & $35,868,949$ \\
Visakhapatnam & $16,436,599$ \\
Mumbai & $7,459,761$ \\
Kakinada & $3,987,957$ \\
Mumbai & $3,574,142$ \\
Delhi Airport & $2,855,270$ \\
Bangalore Airport & $2,088,496$ \\
Hyderabad Airport & 865,081 \\
Chennai Airport & 533,160 \\
Petrapole Land & 388,042 \\
Kolkata Airport & 110,251 \\
Ahmedabad Airport & 77,626 \\
Kochi Airport & 67,443 \\
Seepz & 26,593 \\
SEZ Jamnagar (Reliance) & 3,729 \\
Raxaul Land & 768 \\
Paradip & 455 \\
Total & Intelligence and \\
Note: Directorate & General of Commercial \\
Statistics, Ministry of Commerce and Industry, Govt. of India \\
\end{tabular}


An Indian private sector interviewee also noted the emergence of a large timber-processing zone in Orissa, which was corroborated by the press (The India Telegraph, March 2016). Orissa is situated on the coast of the Bay of Bengal, opposite Myanmar. Although the acquisition of the land for this processing zone seems to have delayed its launch, it is now going ahead. However, the port linked to this processing zone, Paradip, was still far from being the main port of entry of global trade and was not mentioned in the top 11 ports for Myanmar timber flows for 2015.

Most notably, land border points of entry are not mentioned in these tables, although there are two border crossings with customs stations between Myanmar and India: Tamu, Sagaing, Myanmar to Moreh, Manipur, India and Rih, Chin State, Myanmar to Zokhawatar, Mizoram, India. There are two other trading points, located further north along the border, in Arunachal Pradesh (Nampong, India-Pangsu, Myanmar) and Nagaland (Avangku, IndiaSomara, Myanmar), according to the Indian Ministry of Commerce website; these trading points are either nonfunctional or were not officially recognized as of December 2016. As timber trade that does not transit through Yangon is illegal according to Myanmar law, more details will be provided on trade by land entry points in the following section about governance. One could suspect a large flow of illegal timber through the land border.

\section{Main actors of the trade}

Information about the actors of the trade, such as importers, exporters, and analysts of this trade, was gathered from interviews and the literature review. Interview respondents operating in Myanmar highlighted the importance of the national Government and the Myanmar Timber Enterprise in relation to facilitating the timber trade, while respondents operating in India only referred to Indian private companies, generally small and medium-sized enterprises.

Table 4. Port of entry into India of 'Plywood and Allied Products' and 'Other Wood and Wood Products' from Myanmar, Value in US Dollars, 2015

\begin{tabular}{lr}
\hline Port of entry & Value US\$ \\
\hline Cochin & $35,121,479$ \\
Other Ports & $26,797,328$ \\
Kolkata & $25,062,544$ \\
Mundra & $23,113,924$ \\
Delhi (ICD) & $11,343,073$ \\
New Mangalore & $9,505,234$ \\
Nhava Sheva & $7,768,011$ \\
Chennai & $6,832,744$ \\
Visakhapatnam & $5,765,737$ \\
ICD Bangalore & $3,426,436$ \\
Tuticorin & $3,385,327$ \\
Kandla & 860,748 \\
Mumbai & 847 \\
Total & $\mathbf{1 5 8 , 9 8 3 , 4 3 2}$ \\
\hline Note: Directorte
\end{tabular}

Note: Directorate General of Commercial Intelligence and Statistics, Ministry of Commerce and Industry, Govt. of India
The Indian companies involved belong to a relatively new wave of Indian investors that emerged in the 1990s. They had limited links to the Indians who were already established in Myanmar before the Independence. One respondent operating in Myanmar in the private sector explained how the Indian private sector was helpful in bringing financing to the timber sector when Myanmar was isolated from the rest of the world due to economic sanctions and international pressure. Harvesting companies were not able to advance money to pay for transport or staff costs and no financing was available to cover these operating costs of timber extraction. According to this respondent, Indian operators would advance money informally to $\log$ extractors.

Some Indian companies, such as CenturyPly (ICICI Securities Limited 2015) installed processing factories in Myanmar just before the timber ban and it was hoped that other Indian companies would follow suit (ITTO 2015). However, the logging ban has put paid to such hopes and the future of the trade between the two countries is now in doubt. Myanmar was seen as the new production site for a growing Indian market, but this has now slowed down.

\section{Governance}

The India-Myanmar timber trade is partly illegal. Lawson estimates that $17 \%$ of India's imports are of illegal origin (2014, p. 2), while the EIA (2013) estimates that $72 \%$ of Myanmar's exports were illegal between 2000 and 2013. All thirteen respondents, except two closely linked to the Indian private sector, mentioned 'informality' when describing the India-Myanmar timber trade. However, the trade was not so obviously illegal as the China-Myanmar timber trade, which transited up to $94 \%$ (Woods 2015) via the land border of China and Myanmar. Respondents based in New Delhi or at the Myanmar-India border agreed that timber was passing by land, but that the quantities were not significant for two main reasons: first, the rules around the border trade had changed over the last decades and created confusion, secondly and most importantly, the border region was remote for both countries and lacked adequate roads to transport bulky wood products.

Trade links are indeed weak at the Myanmar-India border. India is the neighbor that exchanges the least with Myanmar by land, its trade representing $0.8 \%$ of Myanmar's border trade, with 66 million USD of exchanged value, behind Bangladesh with 1.5 billion USD of trade value at the border, and China with 3.8 billion USD. However, the unofficial Myanmar-India trade was estimated to be much higher, according to interviewees. The border trade was in favor of Myanmar; India imports mainly areca nut (the seed of Areca catechu and commonly referred to as betel nut), dried ginger, medicinal herbs, and also many electronic goods coming from Thailand and China, while Myanmar imports cumin seeds, wheat flour, and Indian cars. This trade differs from the general trade between India and Myanmar and responds to local needs in these isolated regions (Ministry of Commerce 2016).

Because of the lack of currency in Myanmar and the isolation of the region, barter trade was authorized in 1994 for an initial list of 22 commodities, mainly agricultural 
goods. Inhabitants of the border could exchange goods without the use of currency (Annexure 1 in Ministry of Commerce 2016). 'Minor forest products, excluding teak' was one of those commodities. This list was extended in 2007, 2008 and then 2012, reaching 62 items in total. In 2007, 'Wood in the rough, whether or not stripped of bark, timber, wood roughly squared, wood sawn or chipped lengthwise, sliced of a thickness exceeding $25 \mathrm{~mm}$ ' was added as a product that could be imported into India from Myanmar through barter trade (Annexure 2 in Ministry of Commerce 2016). In 2015, barter trade was abolished and normal trade was reintroduced (Annexure 3 in Ministry of Commerce 2016). This change has greatly confused local traders, according to an Indian academic based at the border. This respondent added that trade is ongoing, but since 2015 it is now entirely informal.

Interviewees from researchers from the university and the private sector based in the North-East of India revealed that timber passing the Indo-Myanmar border is traded informally and the trade is substantial, but far from comparable to the Sino-Myanmar trade. They explained that day-time trade consists mainly of imports from Myanmar, originating from China and Mandalay, while informal trade, such as timber, passes the border point at night. One respondent from academia added that there are at least four known points of illegal transit in Manipur alone. Another respondent from the Indian Government noted that Indian border traders originated mainly from Manipur. According to all North-East respondents, timber and medicinal plants transit both ways, from Myanmar into India, and from India, especially the resource-rich NorthEastern states, into Myanmar. Finally, they noted that Burmese timber is used locally in the North-East for housebuilding as it is cheaper than the alternatives and of good quality. Interviewees implied that illegal timber exports to India are most likely sourced from protected forests with bribes being paid to enter such lots in auctions or to pass through customs.

Timber is mainly imported by Indian companies via Yangon port. However, illegality may occur at other points, as explained by Springate et al. (2016). Timber that reaches auction points that Indian traders participate in, may originate from forests that were not supposed to be harvested. Furthermore, during the years when the AAC was exceeded, all Myanmar's timber extraction reporting was very different from its trade partners' statistics and $72 \%$ of the trade was estimated to be illicit. In addition, some respondents operating in Myanmar, especially from civil society, were doubtful about the legality of exchanges run by Indian companies, especially at auctions or at customs. Given the involvement of Indian timber traders in the financing of harvesting operations described above, they may have had unfair advantage in those circumstances. Other respondents in Myanmar, particularly those from the private sector, considered that Indian operators were under much greater scrutiny and could not afford to operate illegally, compared to Myanmar companies.

\section{Prospects for India-Myanmar timber trade}

The India-Myanmar timber trade is dependent on regulations in India and Myanmar, as well as the evolution of relations between the two countries. Respondents based in India were asked about the role of India as a large importer of tropical wood in the international timber trade, and whether civil society or the Government of India recognized the need for regulation to ensure legality and governance of the trade. Civil society has not acted on this topic in recent years and respondents from civil society and international organizations believed that with the current government, it was considered unlikely that they would in the near future. None of the respondents were aware of the WWF Global Forest and Trade Network, except one respondent who participated in its creation. However, the Government of India has shown some interest in timber trade governance, as regulations from export markets, such as the EU or the US, have strengthened. Indeed, according to one respondent working closely with the Indian private sector, the Ministry of Commerce expressed interest at the beginning of 2017 in establishing increased control of timber governance.

Respondents based in Myanmar were negative about the prospects of the timber trade in general. While some respondents from civil society celebrated the fall of the timber market, others, especially those from the private sector, regretted it, noting that not all actors are responsible for the current level of illegality in the sector. All respondents noted that the domestic market is suffering from the current situation. Legal timber does not seem to be available for domestic use, while demand is increasing in the construction sector in particular. As noted by respondents from civil society, while Myanmar is lacking skills and access to financing to develop a thriving wood processing industry, few incentives seem to be in place to develop it.

In this context, Indian companies are suffering. In 2017, the Myanmar government planned to grant timber extraction permits for 19,000 teak trees and 600,000 other hardwood trees; the two respondents from the private sector considered this to be very limited offering relative to industrial demand. One of them noted that an Indian plywood factory was currently functioning at 35\% of its capacity. He added that Indian companies felt very disappointed by the recent changes. These two respondents were very negative about the prospects of the timber market in Myanmar in general. Indian companies say they are adopting a 'wait and see' strategy but it is unclear how long they can wait.

Unrest has dissipated over the past decade in most of the North East of India, but its people are isolated from the rest of India and its neighbors, especially Myanmar. The North East is composed of seven Indian states and is connected to the 'mainland' only via the Siliguri Corridor, which is only $27 \mathrm{~km}$ wide; a landlocked island of the Indian Union. All interview respondents based in the North East confirmed that insurgency had disappeared in almost all of the seven states of this geographical zone, although the states neighboring Myanmar are more unstable than those closer to the Siliguri Corridor. The 20-year period of 
unrest limited exchanges with the North East of India and increased its isolation. In general, Indians based in Assam or Meghalaya, which are closer to Bangladesh, had very limited knowledge about their Eastern neighbor. Few of the academics interviewed had taught Burmese students or met fellow Burmese professors in academic exchanges. This differs from U Thant Myint's description of Universities in Yunnan, China, where 'several of the Chinese academics spoke Burmese well and were knowledgeable on the nittygritty of specific issues, [such as] cross-border trade' (2011).

One of the main points of disagreement between the people of the North East and the Indian Union in the 1990s was the management of natural resources and their land. The Sixth Schedule of the Constitution of India dealt specifically with the states of the North East, ruling local administration and land as well as forest management and acknowledging customary land tenure (Tiwari and Kumar 2008). Timber trade was banned in the North East in 1996 by a Supreme Court decision (Supreme Court of India, 1996). While the current legislation protects land rights and access to resources, its enforcement may vary as the North East opens to economic development.

India and Myanmar had strengthened their ties since the democratic opening of Myanmar in 2011; the Indian Minister of External Affairs was the first foreign dignitary to visit Myanmar when U Thein Sein's government took power. This link was reinforced with the accession of Daw Aung San Suu Kyi to power in 2016; India was the first foreign country she visited. Timber was recently discussed in top-level discussions when Myanmar's Minister of Commerce, U Than Myint and India's Minister of Commerce and Industry, Smt. Nirmala Sitharaman, met in May 2017 (ITTO, June 2017).

The Indian Government plans to improve the connectivity of the North-Eastern states and to connect India to Thailand via Myanmar. The construction of the India-Myanmar-Thailand tri-lateral highway had been discussed since the beginning of the 2000s (Engh 2016). It was formally agreed in 2012 at a meeting in Naypyidaw, Myanmar. Parts of the road have been completed in India and Myanmar; it was scheduled to be completed by 2020 (Ministry of External Affairs 2016). Another important connectivity project, the Kaladan multi-modal project would reconnect the ports of Sittwe, Myanmar, and Kolkata, India and beyond find a route to Mizoram via Myanmar's Chin State, up the Kaladan river. It was also scheduled to be completed by 2020 (Lok Sabha 2017). Interview respondents based in the North East from all sectors were aware of these developments but expressed some doubts about them. First, having heard about these projects since 2000 , some believe they would take longer than planned. Secondly, while these projects were presented as development opportunities, there were fears on both sides of the border about the important social and environmental changes, such as the impacts on forests.

The Kaladan project will connect Sittwe, the capital of Rakhine state, to Mizoram crossing Northern Rakhine. In August 2017, conflict broke out once more in Rakhine state, leading to the displacement of 650,000 Rohingya.
India's Prime Minister, Narendra Modi, chose not to mention the Rohingyas during his state visit in September 2017 but expressed concern over 'extremist violence' (The Hindu, 15 September 2017). It may be in India's interest to develop a pragmatic approach and not directly alienate the Myanmar government on this issue. However, this deeply entrenched conflict will not disappear without intervention. India has economic and diplomatic interests to support the Myanmar government in finding a peaceful and humane solution.

The two countries are becoming closer, both through infrastructure development and diplomatic ties. At the same time, India is likely to remain an accessible market for southeast Asian timber exporters, with fewer requirements than, for example, the EU. The decisions that the Government of Myanmar takes in the next two to three years will be crucial for Indian timber companies operating in Myanmar. While the legality of operations of Indian companies is questioned, their skills and access to finance could prove useful when developing a domestic timber industry. Increased connectivity along their land border will also have an impact on the rich natural resources in that area. In the context of increased road construction, the forests of Sagaing, which have supplied the Indian market over the past two decades, will require careful management if further forest degradation is to be avoided.

\section{CONCLUDING REMARKS}

Until 2014, India-Myanmar timber trade was the most important in terms of value for India and the second most important in terms of volume for Myanmar, after China. Between 2000 and 2015, India accounted for $42 \%$ of the volume of Myanmar's timber exports. In terms of value, however, India's imports from Myanmar were on average $55 \%$ higher than China's on an annual basis.

Round logs were the preferred wood product in this trade and teak the preferred species, representing 95\% and $99 \%$ of the total value of Myanmar exports until 2014. Burmese teak, pyinkado and gurjan were the preferred species. These are not listed in the CITES Appendices, but 'gurjan' includes several species listed as critically endangered on the IUCN Red List. Trade flows most probably transited from Yangon to the ports of Kandla and Mundra in Gujarat until 2013. The main actors of the trade were the Myanmar government, Myanmar Timber Enterprise, its sub-contractors and small and medium Indian enterprises.

After 2014 and the round log export ban enacted by the Government, India-Myanmar timber trade plummeted. Round $\operatorname{logs}$ are now being transformed into plywood or veneer by mills in Myanmar. Gurjan remains the preferred species for plywood and veneer. Burmese teak retains a reputation for great durability, but was not mentioned by private sector actors in Myanmar, possibly because of the recent European sanctions. Trade flows of these products have been transiting through Chennai port. After 2016 and the logging ban, Indian operators that invested in Myanmar 
have adopted a cautious but rather pessimistic 'wait and see' attitude.

The India-Myanmar trade was most likely partially illegal. Myanmar was considered as a high-risk country. Timber sold to Indian traders might not have originated from a forest where extraction was allowed, while timber auction might not be conducted fairly or transparently. However, the volume of timber crossing the Indo-Myanmar border, although substantial, was not comparable to that crossing the Sino-Myanmar border and catered mainly to local needs of the border regions. Illegality was most likely occurring in terms of forest designations, and at the final stages of the timber trade process: auctions and customs.

Although relationship between India and Myanmar was strengthening, in an attempt by both partners to temper the influence of China, timber trade, the second most import item traded by India until 2014, did not seem to be a major topic of discussion yet. However, it would be beneficial for both partners to explore this area jointly. Discussing how Indian companies could survive the governance changes of the Myanmar timber sector in the coming years could also prove useful for the domestic timber market of Myanmar. In addition, including sustainable natural resources management as a key point of discussion in the 'Look East' movement of India's external relations policy, may help increase the social acceptance of the large connectivity projects planned at the border.

The tensions in Northern Rakhine brought to the world's attention will be the main challenge that faces the democratically elected Myanmar government: finding peace for all, while sharing resources equitably. Ethnic minority groups, several of which were still at war, lived where many of the natural resources were located. Their lands were the most forested and were located near the borders of Myanmar's powerful neighbors: China and India. Managing forests in Myanmar is about peace and sharing natural resources among its various ethnic groups, as well as managing relations with its two giant neighbors.

\section{ACKNOWLEDGEMENTS}

The authors would like to thank all interview respondents, who took the time to answer questions. Special thanks are due to those respondents who made recommendations for additional knowledgeable actors. This article has been developed from the Maria-Sube's M.Sc. Thesis, which was completed under the supervision of Woodgate in accordance with the regulations of the MSc in Environmental Management at the School of Oriental and African Studies, University of London, UK.

\section{REFERENCES}

Barua S, Kumar D, Oy I. 2015. SAARC area cross-border timber trade, regional institutional mechanisms and trade link with Myanmar-Some results. European Forest Institute, Helsinki.

Bhatia R. 2016. India-Myanmar Relations, Changing contours. Routledge, New Delhi.
Bryman A. 2012. Social Research Methods. 4th ed. Oxford University Press, Oxford, UK.

Chatham House. 2014. Illegal Wood Import and Re-export: The Scale of the Problem and the Response in Thailand, South Korea and India. Energy, Environment and Resources EER PP 2014/01. London.

Department of Justice. 2012. Gibson Guitar Corp. Agrees to Resolve Investigation into Lacey Act Violations. [Online]. Available from: https://eia-international.org/myanmar-logging-ban-major-step-forestreform [19th February 2017]

Desraj V. 1961. Some Common Burmese Timbers. Student Press. Rangoon.

Engh S. 2016. India's Myanmar Policy and the 'Sino-Indian Great Game'. Asian Affairs 47 (1): 32-58. DOI: 10.1080/03068374.2015.1130307.

Environmental Investigation Agency. 2013. Data Corruption, Exposing the true scale of logging in Myanmar. London, UK.

Environmental Investigation Agency (4th August 2016 (a)) Myanmar logging ban a major step to forest sector reform [Online]. Available from: https://eia-international.org/myanmar-logging-ban-major-stepforest-reform [19th February 2017]

Environmental Investigation Agency (15th November 2016 (b)) Sweden prosecutes Myanmar teak trader-Precedent set for nine further cases and the superyacht sector [Online]. Available from: https://eiainternational.org/sweden-prosecutes-myanmar-teak-trader [20th July 2017]

Environmental Investigation Agency (15th March 2017 (a)) Denmark sanctions entire Burmese teak industry [Online]. Available from: https://eia-international.org/denmark-sanctions-entire-burmese-teakindustry [3rd July 2017]

Environmental Investigation Agency (17th March 2017 (b)) Myanmar gives commitment to legal timber system [Online]. Available from: https://eia-international.org/myanmar-gives-commitment-to-legaltimber-system [Accessed 3rd July 2017]

EU FLEGT Facility, EU-China cooperation to stop illegal logging[Online]. Available from: http://www.euflegt.efi.int/eu-china [19th February 2017]

EU FLEGT Facility. 2007. FLEGT Briefing Notes, What is legal timber? [Online]. Available from: https://ec.europa.eu/europeaid/sites/devco/files/publication-flegtbriefing-note-series-2007-2-200703_en.pdf [19th February 2017]

FAO. 2015a. Global Forest Resources Assessment 2015. Rome.

FAO. 2015b. Global Teak Trade in the Aftermath of Myanmar's Log Export Ban. Rome.

Forest Legality Initiative, Logging and Export Bans [Online]. Available from: http://www.forestlegality.org/content/logging-and-export-bans [19th February 2017]

Forest Trends (22nd November 2016) Swedish Court Rules Myanmar "Green Book" Inadequate for EU Importers [Online]. Available from: http://forest-trends.org/blog/2016/11/22/swedish-court-on-myanmarwood-imports/[19th February 2017]

Gan J, Cerutti P, Masiero M, Pettenella D, Andrighetto N, Dawson T. 2016. Quantifying Illegal Logging and Related Timber Trade. Pages 37-61. In: Kleinschmidt D, Mansourian S, Wildburger C, Purret A (eds.). Illegal Logging and Related Timber Trade-Dimensions, Drivers, Impacts and Responses. A Global Scientific Rapid Response Assessment Report.

Htun K. 2009. Myanmar Forestry Outlook Study. Working paper seriesisep, Working Paper No. APFSOS II/WP/2009/07. FAO, Bangkok.

ICICI Securities Ltd. 2015. Century Plyboards (India) (CENPLY). Retail Equity Research.

ITTO, January 2013. Tropical Timber Market Report. Volume 17 Number 2, 16th-31st January 2013

ITTO. 2015. Biennial review and assessment of the world timber situation. Yokohama, Japan.

ITTO. 2017. Tropical Timber Market Report. Volume 21 Number 12, 16th-30th June 2017

IUCN. 2017. http://www.iucnredlist.org/about/introduction

Kleinschmidt D, Leipold S, Sotirov M. 2016. Introduction: Understanding the Complexities of Illegal Logging and Associated Timber Trade. Pages 13-23. In: Kleinschmidt D, Mansourian S, Wildburger C, Purret A. (eds.). Illegal Logging and Related Timber TradeDimensions, Drivers, Impacts and Responses. A Global Scientific Rapid Response Assessment Report.seppiIUFRO World Series Volume 35.Vienna.

Lok Sabha, Government of India, April 2017, Question No. 6280 Kaladan Multi-Modal Transit Transport. 
Manoharan TR. 2013. Effects of the EU Timber Regulation and the demand for certified legal timber on business and industry in India. European Forest Institute, Helsinki.

Ministry of Commerce and Industry, Government of India. 2016 Enhancing India-Myanmar Border Trade, Policy and Implementation Measures. Ministry of Commerce and Industry, New Delhi, India.

Ministry of Environment and Forests, Government of India, November 2012. Speech of M. F. Farooqui, Special Secretary, Ministry of Environment and Forests at the 6th EU-India Environment Forum on Sustainable Forestry and Biodiversity [Online]. Available from: http://eeas.europa.eu/archives/delegations/india/documents/eu_india/2 012_eu_india_environment_forum/speech_special_secretary_farooqu i_eu_india_environment_forum_21_11_12.pdf [19th February 2017]

Ministry of External Affairs, Government of India, February 2016. India Myanmar Relations [Online]. Available from: https://www.mea.gov.in/Portal/ForeignRelation/Myanamr_Feb_2016. pdf [19th February 2017]

Ministry of External Affairs, Government of India, August 27, 2016 Transcript of Media Briefing by Secretary (ER), JS (BM) and Official Spokesperson (August 26, 2016)".

Singh, A. 2016, India-Myanmar Relations: The Context of Indian Diaspora from History to the Present. In: Ghosh L (ed.). IndiaMyanmar Relations, Historical Links to Contemporary Convergences. Paragon International Publishers, New Delhi.

Springate-Baginski O, Treue T, Htun K. 2016. Legally and Illegally Logged out. University of Copenhagen, Copenhagen.

Supreme Court of India, 12 December 1996. Petitioner: T.N. Godavarman Thrumulkpad. Respondent: Union of India \& Ors. Bench: JS. Verma, BN Kirpal. Retrieved from: http://judis.nic.in/supremecourt/chejudis.asp
Tacconis X. 2016. Defining illegal forest activities and illegal logging. In: Kleinschmidt D, Mansourian S, Wildburger C, Purret A. (eds.). Illegal Logging and Related Timber Trade-Dimensions, Drivers, Impacts and Responses. A Global Scientific Rapid Response Assessment Report.SEP IUFRO World Series Volume 35. Vienna.

Thant Myint U. 2011. Where China Meets India, Burma and the New Crossroads of Asia. Faber and Faber Ltd, London.

The Telegraph India, 16 March 2016. Timber project on fast track [Online]. Available from: https://www.telegraphindia.com/1160316/jsp/odisha/story_74643.jsp . [3rd July 2017]

Tiwari BK, Kumar C. 2008. Forest Products of Meghalaya. Regional Centre, National Afforestation and Eco-development Board, NorthEastern University, Shillong, India.

Wellesley L. 2014. Trade in Illegal Timber The Response in China. is

Woods K, Canby K. 2011. Baseline Study 4 Myanmar: Overview of Forest Law Enforcement, Governance, and Trade. Forest Trends and European Forestry Institute (EFI), Joensuu, Finland.

Woods K. 2013a. Timber Trade Flows and Actors in Myanmar, The Political Economy of Myanmar's Timber Trade. Forest Trends, Washington D.C.

Woods K. 2013b. Analysis of the China-Myanmar Timber Trade. Forest Trends. Washington D.C.

Woods K. 2015. Commercial Agriculture Expansion in Myanmar: Links to Deforestation, Conversion Timber, and Land Conflicts. Forest Trends, Washington D.C. 